\title{
24. LOW-TEMPERATURE ALTERATION OF OCEANIC BASALTS, DSDP LEG 49
}

\author{
Richard G. Pritchard and Johnson R. Cann, Geology Department, Newcastle University, Tyne and Wear, England \\ and \\ David A. Wood, Petrographie-Volcanologie, Batiment 504, University Paris-Sud, France
}

\section{INTRODUCTION}

Alteration of ocean-floor rocks by seawater has been the subject of intensive study in the last four years, especially since the /eep Sea Drilling Project began large-scale penetration of hard rocks of the ocean floor (Andrews, 1977; Bass, 1976; Baragar et al., 1977; Robinson et al., Scarfe and Smith, 1977). Previously, dredged rocks were used for study and the results of the work, summarized by Scott and Hajash (1976), are similar to those already described in the Initial Reports for Legs 34 and 37.

Although our results are similar, we have been able to add significantly to the knowledge of the mineralogy of alteration processes, basalt glass-palagonite changes, and additionally, the chemistry of the alteration fronts which occur close to veins and fractures.

Another alteration mineral, zeolite, occurring mainly as vein material and occasionally as centers of vesicles, has been examined in some detail and has proved to be of the phillipsite type.

Carbonate, especially in veins, is calcite containing low $\mathrm{MgO}$. Most of the $\mathrm{MgO}$ from seawater or olivine phenocryst alteration has gone to form clays.

\section{PETROGRAPHY}

The petrography of the alteration products is described separately in each of the site reports for Leg 49 (see Site Report chapters). This section brings out the more interesting and general conclusions from those reports.

The degree of alteration (defined by the nature and amount of the alteration phases present) varies strikingly with the basement age. The relationship is not perfect, and is difficult to quantify accurately, but the more clearcut distinctions can be described here. Basalts from the youngest hole drilled, 411 , show very little sign of alteration. Olivines are uniformly fresh, but a thin coating of clay minerals occurs on the walls of the vesicles, showing the initial stages of change. The crust here is about $1 \mathrm{~m}$.y. old. Holes 409, 412, and 413, in basement of age 2.3, 1.6, and $3.5 \mathrm{~m} . \mathrm{y}$. respectively, show a greater degree of alteration. Here, some alteration of olivine to clay is found; clusters of carbonate (aragonite and calcite) form on vesicle walls and sometimes replace olivine, and secondary pyrite occurs in veins and ragged blobs in the more reduced parts of the core. Alteration at these three sites does not correspond exactly to age; the rocks from Hole 412 are apparently the most altered, though this is a subjective impression. The older holes, 410,408 and 407 , on crust about 10, 20, and $36 \mathrm{~m} . \mathrm{y}$. old, respectively, show a still greater degree of alteration. Clay minerals are very abundant in the rocks, fresh olivine is nearly confined to the interiors of the yet unaltered fragments of glass in pillow rims, zeolites become abundant near pillow rims, calcite veins are common, and secondary pyrite is common in the reduced parts of the cores. Of these three holes, 408-again not the oldest-shows the greatest degree of alteration.

This relationship between degree of alteration and age strongly suggests that the greater part of the basalt alteration is produced by slow, prolonged percolation of seawater through the basalt pile, rather than by intense hydrothermal activity near the ridge crests. Even in very highly vesicular and therefore permeable basalt, such as that from Hole 409, there is very little alteration, principally, it would seem, because the crust is so young. The different alteration reactions seem to be time dependent, too. Formation of clays is the first visible reaction and continues through the whole alteration period. The next reactions to show are those that precipitate carbonate and secondary pyrite in the rock. Finally, zeolites appear, and clay mineral-calcite veins become common. Alteration of basalt glass only becomes important in the older group of sites, but is never complete. All the cores contain some fresh glass.

The zeolites, when they do form, are very closely associated with the partly altered glassy pillow rims. Within and near these parts of the core, veins filled with zeolites and vesicles partly or wholly occupied by zeolites are common. Zeolites are very rare in association with the massive flow units that make up much of the core, as described in the site reports for this leg (Site Report chapters, this volume). Chemical investigations of the formation of palagonite from glass, described below, suggest that this relationship may be a causal one, with the zeolites, and associated carbonates, forming from the material expelled from basalt glass as alteration takes place.

Very striking in the cores is the division into oxidized and reduced zones. This is especially clear in Hole 408, where a sharp contact in Section 1 of Core 37 divides a more oxidized, buff-colored zone above from a more reduced, blue-gray zone below. Both zones show an equal degree of alteration, but the alteration is of different types. Pyrite, as might be expected, is absent from the oxidized zone, though abundant in the reduced zone. The clay minerals must be different in character too (see below). Other cores show contrasts between oxidized and reduced alteration on a smaller scale, and these have been the subject of chemical investigation.

The clays show a great range in composition (see below), but this range is not accompanied by a corresponding, reliable variation in appearance. Work is at present 
proceeding in relating optical properties of these clays to their mode of occurrence.

\section{MINERALOGY}

The alteration mineralogy is very similar to that observed on Leg 37 (Robinson, Flower, et al., 1977; Scarfe and Smith, 1977; Andrews, 1977), but the present study throws some more light on the clays in particular. Microprobe analyses were made on the electron probe in the Department of Mineralogy and Petrology, Cambridge. X-ray diffraction and optical microscope work were carried out in the School of Environmental Sciences, University of East Anglia. The microprobe analyses suffer from the problems of alkali mobilization and dehydration that affect most analyses of clays and zeolites, and should thus be treated with some caution. In addition, fine-scale interlayering of clays in vesicle linings may have led to averaging of compositions within the bean.

All the microprobe analyses of clays are shown in Figure 1, where $\mathrm{K}_{2} \mathrm{O}$ and $\mathrm{MgO}$ are plotted against total iron calculated as FeO. This method of plotting was adopted to avoid the problems of calculating structural formulas for iron-rich materials where the degree of oxidation of the iron is not known. It conveniently separates the clays into several different types. Examples of each type were selected and can be seen in Table 1. Several sets of analyses in the $\mathrm{FeO}^{*}$ range 13 to 18 per cent are pairs or triples of
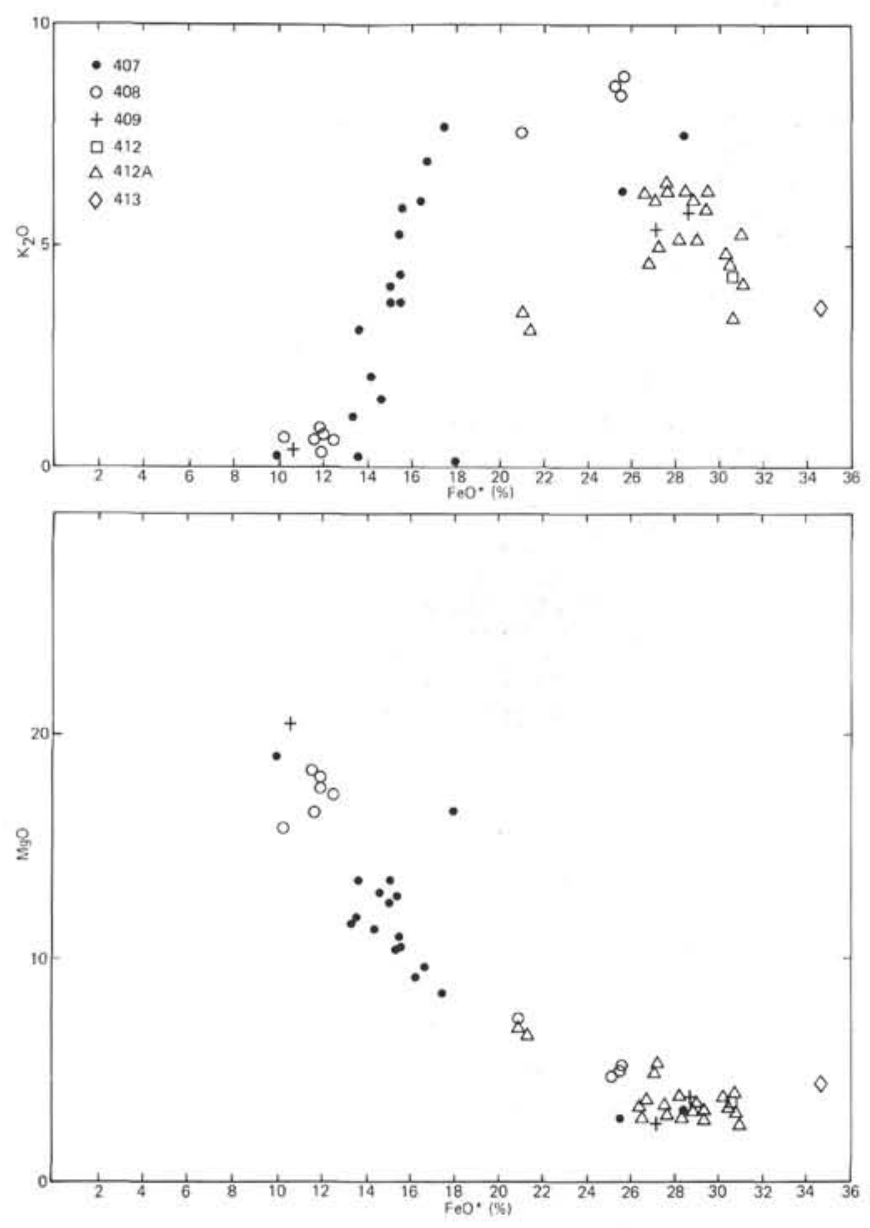

Figure 1. Microprobe analyses of clays. rim-to-center analyses in a single vesicle. A triple set was selected for inclusion in Table 1 (Numbers 3, 4, and 5). The selected analyses are shown separately on Figure 2, along with the rim-to-core vector. The vectors for the other rim-to-core pairs parallel this one.

Two analyses in Table 1, and eleven in Figure 1, from Holes 407, 408, and 409, are of smectites. Calculation of structural formulas suggests strongly that they are reduced tri-octahedral saponites, with $\mathrm{Mg}$ greater than twice $\mathrm{Fe}$ in the octahedral sites. The other analyses in Table 1 are more illitic. At the extreme, Numbers 7 through 10, they are oxidized, yellow to brown, dioctahedral iron-rich illites (celadonites). Numbers 3 through 6 of Table 1 are not purely dioctahedral iron-rich illites (celadonites). Numbers 3 through 6 of Table 1 are not purely dioctahedral or trioctahedral, as far as can be told from the probe analyses, and have intermediate characters. The rim-to-center pairs and triples show that the material deposited earlier (the rim) is more saponitic, and the later material celadonitic. In thin section, the saponites are yellow or brown and the celadonites more greenish, but in hand specimen, the celadonite is often a pale celadon blue.

The occurrence of saponite in forming rims and celadonite the centers of vesicles suggests an earlier, more reducing phase of alteration, during which the saponite formed was succeeded by a later oxidizing phase producing the celadonite, and which removed $\mathrm{K}$ from interstitial solutions.

Table 2 shows analyses of zeolites from Leg 49. X-ray diffraction gives patterns similar to those of other oceanic phillipsites (Pritchard, in preparation; Hay, 1966). The microprobe analyses are very close to those reported from Leg 37, with $\mathrm{Si} / \mathrm{Al}$ ratios of around 2.5 , well within the range reported for phillipsite (1.3 to 3.4, Hay, 1966).

Calcite is the only carbonate confirmed by X-ray diffraction, though aragonite was detected petrographically in some of the younger holes. Microprobe analyses of a vein calcite show it to contain 2.0 per cent $\mathrm{MgO}$.

\section{ALTERATION OF BASALT GLASS}

The glassy pillow margins in the pillowed parts of the cores contain fresh glass in all the holes. However, this is usually partly altered to bright yellow palagonite around its edges and along cracks penetrating through the glass. The palagonite is very frequently associated with veins filled with zeolites and carbonate. In fact, zeolites are rare in all the holes of Leg 49 , except in the vicinity of such partly altered glassy margins. Five chemical analyses of glass-palagonite pairs are presented in Table 3 . These were carried out by electron probe at the Department of Mineralogy and Petrology, Cambridge, as were all of the other mineral analyses reported in this paper.

The alteration of basalt glass to palagonite is essentially a metasomatic problem, and, as in all such problems, knowledge of starting and finishing states is not sufficient to define the nature of the process involved; some additional assumption must be made. In a parallel study on Leg 36 lavas, Scarfe and Smith (1977) make the assumption, classic in petrology, that volume has remained unchanged during the process. On this basis, $\mathrm{Si}, \mathrm{Al}, \mathrm{Mn}, \mathrm{Ca}$, and $\mathrm{Na}$ show a removal, while $\mathrm{Ti}, \mathrm{Fe}$, and $\mathrm{K}$ must be added. The 
TABLE 1

Microprobe Analyses of Representative Clay Minerals (normalized to 22 oxygens in lower half)

\begin{tabular}{|c|c|c|c|c|c|c|c|c|c|c|}
\hline $\begin{array}{c}\text { Sample } \\
\text { (Interval in } \mathrm{cm} \text { ) }\end{array}$ & $\begin{array}{l}408-37-1, \\
26-29 \text { (a) }\end{array}$ & $\begin{array}{l}408-37-1 \\
26-29 \text { (b) }\end{array}$ & $\begin{array}{l}\text { 407-45-1, } \\
115-120(\mathrm{R})\end{array}$ & $\begin{array}{c}407-45-1 \\
115-120(\mathrm{M})\end{array}$ & $\begin{array}{c}\text { 407-45-1, } \\
115-120(C)\end{array}$ & $\begin{array}{c}412 \mathrm{~A}-14-3 \\
51-53\end{array}$ & $\begin{array}{c}408-37-1, \\
26-29 \text { (c) }\end{array}$ & $\begin{array}{l}412 \mathrm{~A}-9-1 \\
80-82\end{array}$ & $\begin{array}{c}409-19-1, \\
15-20\end{array}$ & $\begin{array}{c}412 \mathrm{~A}-7-2, \\
28-30\end{array}$ \\
\hline $\mathrm{SiO}_{2}$ & 40.78 & 42.13 & 42.30 & 48.77 & 52.22 & 45.61 & 50.82 & 43.84 & 47.75 & 44.02 \\
\hline $\mathrm{TiO}_{2}^{2}$ & - & - & - & 0.25 & 0.20 & - & - & - & - & - \\
\hline $\mathrm{Al}_{2} \mathrm{O}_{3}$ & 4.87 & 7.37 & 3.62 & 3.56 & 3.07 & 2.21 & 1.84 & 2.75 & 1.25 & - \\
\hline $\mathrm{FeO}^{*}$ & 10.14 & 12.02 & 13.41 & 15.48 & 17.29 & 21.22 & 25.76 & 26.51 & 28.59 & 30.87 \\
\hline $\mathrm{MgO}$ & 15.95 & 17.69 & 11.67 & 10.93 & 8.22 & 6.54 & 4.78 & 2.86 & 3.77 & 3.14 \\
\hline $\mathrm{CaO}$ & 0.92 & 1.68 & 0.40 & 0.28 & 0.37 & 1.97 & 0.25 & 0.79 & 0.62 & 1.22 \\
\hline $\mathrm{Na}_{2} \mathrm{O}$ & 1.31 & - & 0.49 & - & - & 0.84 & - & 0.27 & - & 0.57 \\
\hline $\mathrm{K}_{2} \mathrm{O}$ & 0.65 & 0.34 & 3.12 & 5.27 & 7.71 & 3.08 & 8.95 & 5.57 & 5.78 & 4.17 \\
\hline $\mathrm{CuO}$ & 2.09 & 0.43 & 0.46 & - & - & 0.06 & - & 0.14 & - & - \\
\hline $\mathrm{SO}_{2}$ & 0.41 & 0.33 & - & - & - & 0.06 & - & - & - & - \\
\hline Total & 77.13 & 82.16 & 75.47 & 84.52 & 89.06 & 82.48 & 92.11 & 82.72 & 87.76 & 84.01 \\
\hline \multicolumn{11}{|l|}{ Cats/220's } \\
\hline $\mathrm{Si}$ & 7.03 & 6.77 & 7.58 & 7.83 & 8.07 & 7.28 & 7.46 & 7.16 & 7.32 & 7.12 \\
\hline $\mathrm{Al}_{\mathrm{IV}}^{\mathrm{IV}}$ & 0.97 & 1.23 & 0.42 & 0.17 & - & 0.41 & 0.31 & 0.72 & 0.22 & - \\
\hline $\mathrm{Fe}^{\mathrm{IV}}$ & - & - & - & - & - & 0.31 & 0.23 & 0.12 & 0.46 & 0.88 \\
\hline $\mathrm{Al}_{\mathrm{VI}}^{\mathrm{VI}}$ & 0.02 & 0.17 & 0.25 & 0.50 & 0.56 & - & - & - & - & - \\
\hline $\mathrm{Fe}^{\mathrm{VI}}$ & 1.46 & 1.62 & 2.01 & 2.08 & 2.23 & 2.52 & 2.90 & 3.50 & 3.21 & 3.30 \\
\hline $\mathrm{Mg}$ & 4.09 & 4.24 & 3.01 & 2.61 & 1.89 & 1.55 & 1.04 & 0.70 & 0.86 & 0.77 \\
\hline $\mathrm{Cu}$ & 0.28 & 0.05 & - & - & - & 0.07 & - & 0.02 & - & - \\
\hline $\mathrm{Ca}$ & 0.17 & 0.28 & 0.08 & 0.05 & 0.06 & 0.34 & 0.04 & 0.14 & 0.10 & 0.21 \\
\hline $\mathrm{Na}$ & 0.44 & - & 0.17 & - & - & 0.26 & - & 0.09 & - & 0.17 \\
\hline $\mathrm{K}$ & 0.14 & 0.07 & 0.72 & 1.08 & 1.52 & 0.63 & 1.80 & 1.17 & 1.13 & 0.87 \\
\hline sOct & 5.85 & 6.08 & 5.27 & 5.22 & 4.70 & 4.14 & 3.94 & 4.22 & 4.07 & 4.07 \\
\hline
\end{tabular}

Note: (a), (b), and (c) are from the same sample; (R), (M), and (C) indicate rim, middle, and core of vesicle fill.


Figure 2. Selected microprobe analyses from Figure 1 (Rim $=\operatorname{rim}, C=$ center . addition of $\mathrm{Ti}$ and $\mathrm{Fe}$ in rather large quantities seems to us unlikely, and this is particularly true of Ti. Not only does Ti generally behave as a relatively immobile element during a large variety of basalt alteration processes (Cann, 1970; Robinson, Flower, et al., 1977), but the minerals in these basalts that fill veins or vesicles, and thus must have involved fluid transport, are invariably very poor in $\mathrm{Ti}$ (see the tables in this and other reports). A closer approximation to the actual state of affairs might thus be possible by assuming that Ti remained immobile; the differences in the percentages of $\mathrm{TiO}_{2}$ in fresh and altered material would then be the result of large-scale leaching of the other components. The results of a calculation along these lines are shown in Table 4. Now every component except $\mathrm{TiO}_{2}$ (by definition), $\mathrm{K}_{2} \mathrm{O}$, and $\mathrm{H}_{2} \mathrm{O}$ (not directly analyzed) shows depletion. In support of this assumption, it is interesting that $\mathrm{Si} / \mathrm{Al}$ ratios in the calculated leaches are close to those of the zeolites that were analyzed from nearby in the same samples (see Table 2), and that the large amount of $\mathrm{Ca}$ calculated as removed could account for some of the abundant carbonate veining in these pillow margins.

The alteration of glass to palagonite occurs by a sharp transition. Intermediate materials are not seen, and this is brought out well by the analyses in Table 5 and the results of the calculation in Table 4 . No progressive gradation is visible in chemical terms. For this reason, it seemed likely that the formation of palagonite might be controlled by crystal structure. Recalculation of the chemical analyses might thus give results corresponding to some clay mineral phase in equilibrium with the oxidative pore waters present. The results of such a calculation are presented in Table 4 . 
TABLE 2

Microprobe Analyses of Zeolites (normalized to 72 oxygens in lower half)

\begin{tabular}{lccccccccc}
\hline \multicolumn{1}{c}{ Sample } & $407-45-2$, & $407-46-2$, & $407-46-2$, & $407-46-3$, & $407-46-3$, & $407-46-4$, & $407-46-4$ & $410-39-2$, & $410-39-2$, \\
(Interval in cm) & $75-80$ & $120-122$ & $120-122$ & $37-42$ & $37-42$ & $3-5(\mathrm{a})$ & $3-5(\mathrm{~b})$ & $124-126(\mathrm{a})$ & $124-126(\mathrm{~b})$ \\
\hline $\mathrm{SiO}_{2}$ & 51.35 & 53.92 & 53.30 & 53.33 & 52.80 & 55.30 & 55.18 & 56.06 & 55.96 \\
$\mathrm{Al}_{2} \mathrm{O}_{3}$ & 19.98 & 17.40 & 17.00 & 18.28 & 17.86 & 17.78 & 17.72 & 19.28 & 18.82 \\
$\mathrm{FeO}$ & 0.41 & - & 0.19 & - & - & - & - & - & - \\
$\mathrm{P}_{2} \mathrm{O}_{5}$ & - & - & - & - & - & 0.23 & 0.27 & - & - \\
$\mathrm{CaO}$ & 0.60 & - & 0.13 & - & 0.32 & 0.13 & 0.36 & 0.10 & 0.16 \\
$\mathrm{Na}_{2} \mathrm{O}$ & 2.88 & 5.90 & 4.09 & 3.86 & 3.99 & 2.42 & 2.83 & 3.72 & 3.33 \\
$\mathrm{~K}_{2} \mathrm{O}$ & 8.38 & 7.04 & 8.91 & 7.97 & 8.52 & 7.45 & 7.58 & 7.90 & 7.80 \\
$\mathrm{Total}$ & 83.60 & 84.27 & 83.62 & 83.44 & 83.49 & 83.31 & 83.94 & 87.06 & 86.06 \\
& & & & & & & & \\
$\mathrm{Cats} / 720$ 's & & & & & & & & \\
$\mathrm{Si}$ & 25.13 & 26.08 & 26.18 & 25.98 & 25.89 & 26.58 & 26.44 & 26.04 & 26.24 \\
$\mathrm{Al}$ & 11.52 & 9.92 & 9.84 & 10.50 & 10.32 & 10.08 & 10.02 & 10.56 & 10.40 \\
$\mathrm{Fe}$ & 0.17 & - & 0.08 & - & - & - & - & - & - \\
$\mathrm{P}$ & - & - & - & - & - & 0.09 & 0.11 & - & - \\
$\mathrm{Ca}$ & 0.32 & - & 0.08 & - & 0.17 & 0.06 & 0.19 & 0.05 & 0.08 \\
$\mathrm{Na}$ & 2.73 & 5.54 & 3.90 & 3.65 & 3.79 & 2.25 & 2.63 & 3.35 \\
$\mathrm{~K}$ & 5.23 & 4.34 & 5.58 & 4.95 & 5.33 & 4.56 & 4.64 & 4.68 & 3.03 \\
$\mathrm{Z}$ & 36.65 & 36.00 & 36.02 & 36.48 & 36.63 & 36.66 & 36.46 & 36.60 & 3.66 \\
$\mathrm{R}$ & 8.60 & 9.66 & 9.64 & 8.60 & 9.46 & 6.93 & 7.65 & 8.13 & 7.85 \\
\hline
\end{tabular}

Note: $\mathrm{R}=2 \mathrm{Ca}+\mathrm{Na}+\mathrm{K} ; \mathrm{Z}=\mathrm{Si}+\mathrm{Al} ;-$ indicates not detected.

TABLE 3

Microprobe Analyses of Fresh and Altered Glasses From the Same Samples

\begin{tabular}{|c|c|c|c|c|c|c|c|c|c|c|}
\hline \multirow[t]{2}{*}{$\begin{array}{c}\text { Sample } \\
\text { (Interval in } \mathrm{cm} \text { ) }\end{array}$} & \multicolumn{2}{|c|}{$407-45-2,75-82$} & \multicolumn{2}{|c|}{$407-46-3,37-42$} & \multicolumn{2}{|c|}{$407-46-4,3-5$} & \multicolumn{2}{|c|}{$409-13-2,115-121$} & \multicolumn{2}{|c|}{$410 \mathrm{~A}-4-3,30-34$} \\
\hline & Fresh & Altered & Fresh & Altered & Fresh & Altered & Fresh & Altered & Fresh & Altered \\
\hline $\mathrm{SiO}_{2}$ & 49.04 & 39.95 & 49.46 & 43.15 & 49.63 & 39.39 & 49.99 & 36.94 & 50.69 & 33.58 \\
\hline $\mathrm{TiO}_{2}$ & 1.92 & 3.74 & 1.92 & 3.10 & 1.90 & 2.99 & 1.53 & 2.86 & 1.24 & 2.32 \\
\hline $\mathrm{Al}_{2} \mathrm{O}_{3}$ & 15.69 & 10.71 & 14.05 & 9.91 & 14.48 & 11.63 & 13.26 & 7.02 & 16.61 & 17.40 \\
\hline $\mathrm{FeO}^{*}$ & 11.93 & 20.38 & 12.61 & 19.36 & 12.11 & 17.39 & 12.25 & 21.65 & 7.97 & 12.23 \\
\hline $\mathrm{MnO}_{2}$ & 0.15 & - & 0.22 & - & 0.22 & - & 0.21 & - & 0.14 & - \\
\hline $\mathrm{MgO}^{2}$ & 6.23 & 2.97 & 6.52 & 3.32 & 6.61 & 2.63 & 6.10 & 5.55 & 7.12 & 0.99 \\
\hline $\mathrm{CaO}$ & 10.93 & 1.94 & 11.42 & 1.78 & 11.24 & 1.45 & 11.38 & 0.66 & 11.00 & 1.61 \\
\hline $\mathrm{Na}_{2} \mathrm{O}$ & 2.49 & 0.93 & 2.48 & - & 2.60 & 1.89 & 2.13 & - & 2.80 & 1.85 \\
\hline $\mathrm{K}_{2} \mathrm{O}$ & 0.19 & 3.25 & 0.25 & 3.67 & 0.21 & 3.56 & 0.18 & 4.05 & 0.85 & 2.57 \\
\hline $\mathrm{P}_{2} \mathrm{O}_{5}$ & 0.30 & - & 0.31 & - & 0.36 & - & 0.31 & - & 0.34 & - \\
\hline Total & 98.87 & 83.86 & 99.24 & 84.28 & 99.36 & 80.93 & 97.34 & 88.73 & 98.76 & 72.55 \\
\hline
\end{tabular}

Note: ${ }^{*} \mathrm{FeO}$ represents total iron. All oxides in weight per cent; - indicates not detected.

For the purposes of the calculation, $\mathrm{TiO}_{2}$ was assumed to be present as an oxide phase, and the rest of the analyses were calculated to 22 oxygens, as is appropriate for clays when $\mathrm{OH}$ is not known. All the palagonite analyses calculate very well to a dioctahedral illite composition, with interlayer cations ranging from 0.89 to 1.64 . The higher values are more likely to be correct, since the probe technique used may not detect small amounts of $\mathrm{Na}_{2} \mathrm{O}$. Compared with the other clays analyzed (see above), these clays are poorer in silicon and richer in aluminum, probably reflecting their origin as a residual phase rather than as precipitates from solution.

The results of this calculation suggest that the transformation of glass to palagonite may very well be controlled by the clay mineral structure forming. This must itself be a function of parent material, in this case basalt glass, and of composition of the solution (probably cold seawater).

\section{BULK CHEMICAL ALTERATION}

Six hand specimens were selected for this study. They were chosen because they showed obvious variation in the style of alteration: a sharp boundary separated a pale gray region from either a dark gray or yellow-gray to yellow-orange region.

These samples were cut by diamond saw so that the two areas were separated. The fragments were carefully washed with distilled water, dried at room temperature, then 
TABLE 4

Results of the Calculation of Material Removed From the Basalt Glasses of Table 3 to Form Their Coexisting Palagonites $\left(\mathrm{TiO}_{2}\right.$ is assumed immobile in this calculation. Numbers quoted are $\mathrm{kg}$ removed from every $100 \mathrm{~kg}$ of original glass; the negative sign by $\mathrm{K}_{2} \mathrm{O}$ indicates addition of this component; further discussion is in the text.)

\begin{tabular}{lccccc}
\hline $\begin{array}{c}\text { Sample } \\
\text { (Interval in cm) }\end{array}$ & $\begin{array}{c}407-45-2, \\
75-82\end{array}$ & $\begin{array}{c}407-46-3, \\
37-42\end{array}$ & $\begin{array}{c}407-46-4, \\
3-5\end{array}$ & $\begin{array}{c}409-13-2, \\
115-121\end{array}$ & $\begin{array}{c}410 \mathrm{~A}-4-3 \\
30-34\end{array}$ \\
\hline $\mathrm{SiO}_{2}$ & 28.53 & 22.74 & 24.60 & 24.88 & 32.74 \\
$\mathrm{TiO}_{2}$ & 0 & 0 & 0 & 0 & 0 \\
$\mathrm{Al}_{2} \mathrm{O}_{3}$ & 10.19 & 7.91 & 7.09 & 9.50 & 7.31 \\
$\mathrm{FeO}^{*}$ & 1.47 & 0.62 & 1.06 & 0.67 & 1.43 \\
$\mathrm{MnO}_{2}$ & 0.15 & 0.22 & 0.22 & 0.21 & 0.14 \\
$\mathrm{MgO}_{\mathrm{CaO}}$ & 4.71 & 4.46 & 4.94 & 3.13 & 6.59 \\
$\mathrm{Na}_{2} \mathrm{O}$ & 9.93 & 10.31 & 10.32 & 11.03 & 10.14 \\
$\mathrm{~K}_{2} \mathrm{O}$ & 2.01 & 2.48 & 1.40 & 2.13 & 1.81 \\
$\mathrm{P}_{2} \mathrm{O}_{5}$ & -1.48 & -2.02 & -2.05 & -1.99 & -0.52 \\
Total & 0.30 & 0.31 & 0.36 & 0.31 & 0.34 \\
& 55.81 & 47.03 & 47.94 & 49.87 & 59.98 \\
\hline
\end{tabular}

Note: * FeO represents total iron.

TABLE 5

Structural Formulas of Palagonites (altered glasses) (calculated on the basis of 22 oxygens, assuming all iron is present in the ferric state; $\mathrm{TiO}_{2}$ has been omitted from the calculation [see text])

\begin{tabular}{lccccc}
\hline $\begin{array}{c}\text { Sample } \\
\text { (Interval in cm) }\end{array}$ & $\begin{array}{c}407-45-2, \\
75-82\end{array}$ & $\begin{array}{c}407-46-3, \\
37-42\end{array}$ & $\begin{array}{c}407-46-4, \\
3-5\end{array}$ & $\begin{array}{c}409-13-2, \\
115-121\end{array}$ & $\begin{array}{c}410 \mathrm{~A}-4-3, \\
30-34\end{array}$ \\
\hline $\mathrm{Si}$ & 6.53 & 6.88 & 6.63 & 7.12 & 6.16 \\
$\mathrm{Al}^{\mathrm{IV}}$ & 1.47 & 1.12 & 1.37 & 0.88 & 1.84 \\
$\mathrm{Al}$ & 0.59 & 0.74 & 0.94 & 0.38 & 1.92 \\
$\mathrm{Fe}$ & 2.79 & 2.58 & 2.45 & 2.75 & 1.88 \\
$\mathrm{Mg}$ & 0.72 & 0.79 & 0.66 & 1.25 & 0.27 \\
$\mathrm{Ca}$ & 0.34 & 0.42 & 0.26 & 0.11 & 0.32 \\
$\mathrm{Na}$ & 0.29 & - & 0.62 & - & 0.65 \\
$\mathrm{~K}$ & 0.68 & 0.75 & 0.76 & 0.78 & 0.60 \\
$\mathrm{Oct}^{\mathrm{a}}$ & 4.10 & 4.11 & 4.05 & 4.38 & 4.07 \\
\hline
\end{tabular}

${ }^{\mathrm{a}} \mathrm{Oct}$ is the sum of $\mathrm{Al}^{\mathrm{VI}}, \mathrm{Fe}$, and $\mathrm{Mg}$.

crushed by percussion mortar to pass a $120 \mu \mathrm{m}$ stainless steel mesh, and homogenized and air-dried at $105^{\circ} \mathrm{C}$ overnight. The powders were then formed into borate glass beads (Norrish and Hutton, 1967) for subsequent X-ray fluorescence analysis. Separate samples were used for determination of $\mathrm{Na}_{2} \mathrm{O}$ and $\mathrm{FeO}$ by the standard methods. The analyses were carried out at the University of East Anglia.

The complete analyses are shown in Table 6 , where it is evident that in what appears to be a more altered zone there is a fall in $\mathrm{MgO}$ and $\mathrm{FeO} / \mathrm{Fe}_{2} \mathrm{O}_{3}$ and an increase in $\mathrm{K}_{2} \mathrm{O}$, $\mathrm{Na}_{2} \mathrm{O}$, total iron, and loss on ignition. The other elements do not change significantly, however. A more interesting trend is apparent when $\mathrm{MgO}$ and $\mathrm{K}_{2} \mathrm{O}$ are plotted against loss on ignition (L.O.I.) (Figure 3). In general, the rocks are already altered, as is shown by the loss on ignition. The subsequent changes are of two types, either a relatively small or large change in loss on ignition, compared with that of $\mathrm{K}_{2} \mathrm{O}$, shown by the two sets of gradients in the lower half of Figure 3.

The original basaltic materials, from which these samples were derived, must have started with an original composition that would plot in the bottom left of the $\mathrm{K}_{2} \mathrm{O}$ -
TABLE 6

Bulk Chemical Analyses of Adjacent Relatively Unaltered/ Altered Leg 49 Basalts (ignited basis)

\begin{tabular}{|c|c|c|c|c|c|c|}
\hline $\begin{array}{c}\text { Sample } \\
\text { (Interval in } \mathrm{cm} \text { ) }\end{array}$ & \multicolumn{2}{|c|}{$\begin{array}{c}408-37-1 \\
26-29\end{array}$} & \multicolumn{2}{|c|}{$\begin{array}{c}412 \mathrm{~A}-3-2 \\
114-117\end{array}$} & \multicolumn{2}{|c|}{$\begin{array}{c}412 \mathrm{~A}-7-2 \\
28-30\end{array}$} \\
\hline $\mathrm{SiO}_{2}$ & 49.94 & 46.27 & 50.47 & 51.08 & 50.14 & 50.99 \\
\hline $\mathrm{TiO}_{2}$ & 1.64 & 1.64 & 1.0 & 0.94 & 1.00 & 0.99 \\
\hline $\mathrm{Al}_{2} \mathrm{O}_{3}$ & 15.55 & 14.18 & 15.40 & 14.60 & 15.30 & 15.21 \\
\hline $\mathrm{Fe}_{2} \mathrm{O}_{3}$ & 3.86 & 11.19 & 4.18 & 5.34 & 2.35 & 3.90 \\
\hline $\mathrm{Fe}_{2} \mathrm{O}$ & 5.87 & 4.39 & 6.74 & 4.94 & 7.46 & 6.35 \\
\hline $\mathrm{MgO}$ & 7.89 & 7.60 & 7.61 & 8.11 & 7.99 & 6.70 \\
\hline $\mathrm{MnO}$ & 0.13 & 0.16 & 0.17 & 0.18 & 0.16 & 0.19 \\
\hline $\mathrm{CaO}$ & 12.24 & 11.43 & 12.63 & 12.25 & 12.72 & 12.66 \\
\hline $\mathrm{Na}_{2} \mathrm{O}$ & 2.29 & 2.50 & 1.95 & 2.23 & 2.36 & 2.34 \\
\hline $\mathrm{K}_{2} \mathrm{O}$ & 0.21 & 0.65 & 0.11 & 0.34 & 0.10 & 0.19 \\
\hline $\mathrm{P}_{2} \mathrm{O}_{5}$ & 0.21 & 0.19 & 0.11 & 0.12 & 0.12 & 0.13 \\
\hline Total & 99.83 & 100.20 & 100.38 & 100.13 & 99.70 & 99.65 \\
\hline L.O.I. & 1.14 & 2.23 & 0.60 & 0.70 & 0.30 & 0.58 \\
\hline $\begin{array}{c}\text { Sample } \\
\text { (Interval in } \mathrm{cm} \text { ) }\end{array}$ & \multicolumn{2}{|c|}{$\begin{array}{c}412 \mathrm{~A}-14-1, \\
123-126\end{array}$} & \multicolumn{2}{|c|}{$\begin{array}{l}412 \mathrm{~A}-14-3, \\
51-53\end{array}$} & \multicolumn{2}{|c|}{$\begin{array}{l}413-4-1, \\
6-10\end{array}$} \\
\hline $\mathrm{SiO}_{2}$ & 50.46 & 50.28 & 50.98 & 49.43 & 48.00 & 46.91 \\
\hline $\mathrm{TiO}_{2}$ & 0.98 & 1.01 & 1.04 & 0.99 & 0.70 & 0.76 \\
\hline $\mathrm{Al}_{2} \mathrm{O}_{3}$ & 14.91 & 14.96 & 15.10 & 16.56 & 16.27 & 17.97 \\
\hline $\mathrm{Fe}_{2} \mathrm{O}_{3}$ & 3.91 & 4.34 & 7.32 & 6.95 & 4.93 & 3.33 \\
\hline $\mathrm{FeO}$ & 7.33 & 6.92 & 2.53 & 2.44 & 5.46 & 8.31 \\
\hline $\mathrm{MgO}$ & 7.22 & 7.08 & 7.64 & 7.64 & 10.68 & 7.11 \\
\hline $\mathrm{MnO}_{2}$ & 0.19 & 0.19 & 0.12 & 0.17 & 0.17 & 0.18 \\
\hline $\mathrm{CaO}$ & 12.30 & 12.53 & 12.43 & 13.26 & 11.42 & 12.11 \\
\hline $\mathrm{Na}_{2} \mathrm{O}$ & 2.19 & 2.29 & 2.17 & 2.26 & 2.09 & 2.91 \\
\hline $\mathrm{K}_{2} \mathrm{O}$ & 0.22 & 0.30 & 0.09 & 0.10 & 0.03 & 0.11 \\
\hline $\mathrm{P}_{2} \mathrm{O}_{5}$ & 0.11 & 0.12 & 0.12 & 0.15 & 0.03 & 0.17 \\
\hline Total & 99.82 & 100.02 & 99.55 & 99.95 & 99.78 & 99.87 \\
\hline L.O.I. & 0.47 & 0.55 & 0.39 & 0.72 & 0.03 & 2.17 \\
\hline
\end{tabular}

Note: Right-hand analysis of each pair is "altered."

versus- L.O.I. graph. Five of the six, then, are already altered, but the subsequent alteration undergone by their respective "altered" zones is of two types.

The alteration of one clay type to another, i.e., saponitic to celadonitic, could account for the merely slight increase in loss on ignition with a large change in $\mathrm{K}_{2} \mathrm{O}$, whereas the increase in loss on ignition without concomitant $\mathrm{K}_{2} \mathrm{O}$ could be explained by production of additional saponitic clay from the basalt.

\section{SUMMARY}

1. The predominantly pale yellow $\mathrm{Mg}$-saponites form before the green (pale blue in hand specimen) $\mathrm{K}-\mathrm{Fe}$-celadonites; there is some evidence for saponite to celadonite transformation.

2. The zeolites are of the phillipsite type and occur mainly in veins, so must have been crystallized from solution.

3. Calcite is another common vein fill, although it occasionally occupies vesicles.

4. The sequence of alteration is primary alteration of olivine phenocrysts and parts of the glass to saponite, followed by formation of celadonite, mainly in veins and empty interstices, which may be cut by later carbonate (calcite in these samples) or zeolite veins. Secondary pyrite also occurs.

5. In the case of clays formed at the basalt glass/palagonite interface, the composition of the clay 

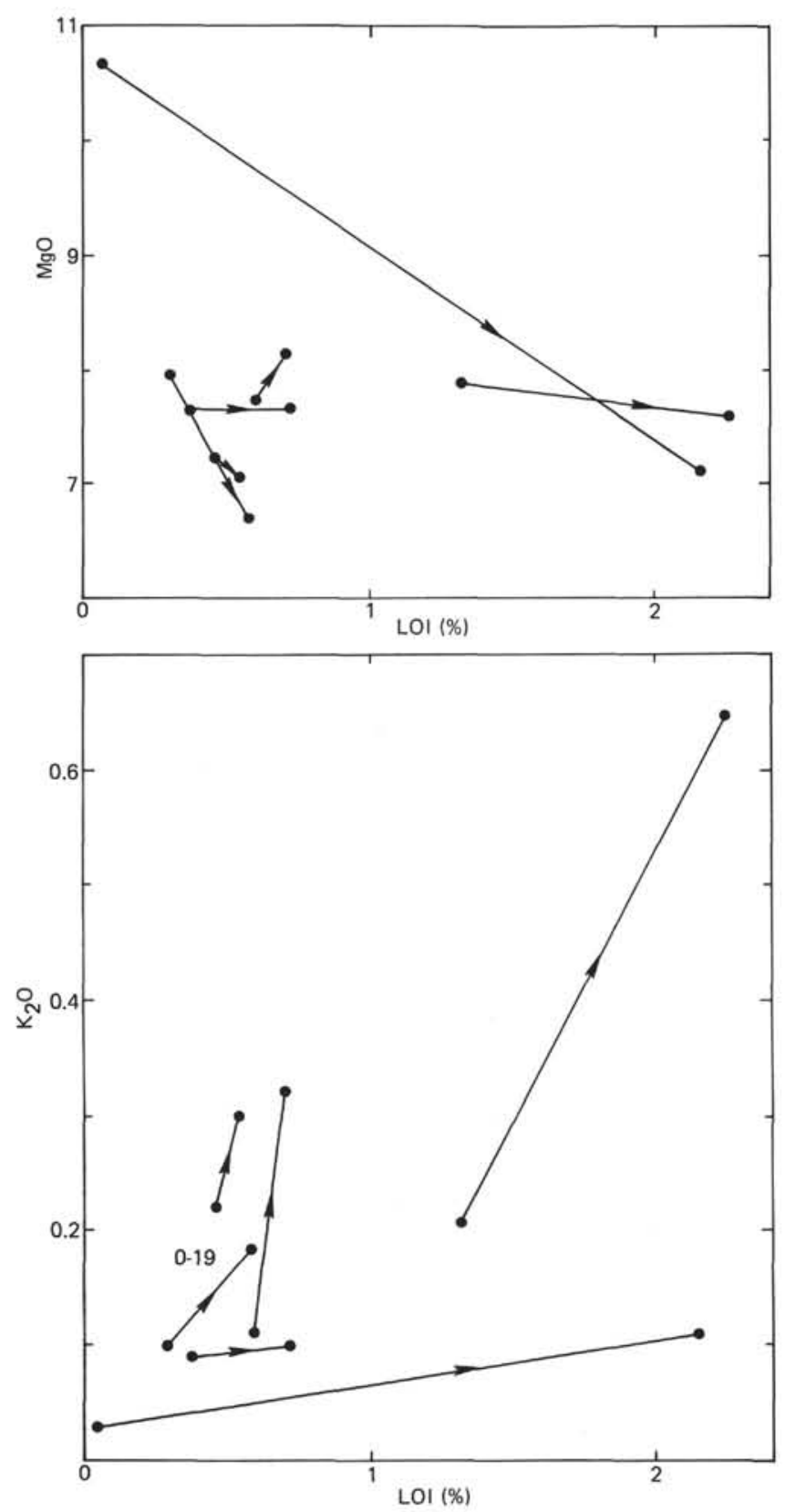

Figure 3. Alteration trends in Leg 49 basalts. forming depends on the chemistry of the glass and of the interacting seawater.

6. In the long term, the degree of alteration increases with the time during which the basalt interacts with the seawater. In the short term, it depends on the relative permeabilities; thus, with rocks of about the same age, the older may be the least altered.

\section{ACKNOWLEDGMENTS}

Sincere thanks are due to W. Porter, N. Charley, and J. V. P. Long (Cambridge University) for assistance with the microprobe analyses. C. K. Winter (University of East Anglia) provided help with the X-ray diffraction and fluorescence analyses. R. G. Pritchard was supported during this work with a grant from the Natural Environmental Research Council. This report was reviewed by $\mathrm{H}$. Prichard, Geology Department, Newcastle University.

\section{REFERENCES}

Andrews, A. J., 1977. Low temperature fluid alteration of oceanic layer 2 basalts, DSDP Leg 37, Canadian J. Earth Sci., v. 14, p. $911-926$.

Baragar, W. R. A., et al., 1977. Petrology and alteration of selected units of Mid-Atlantic Ridge basalts sampled from sites 332 and 335, DSDP, Canadian J. Earth Sci., v. 14, p. $837-874$

Bass, M. N., 1976. Secondary minerals in oceanic basalt, with special reference to Leg 34, DSDP. In Yeats, R. S., Hart, S. R., et al., Initial Reports of the Deep Sea Drilling Project, v. 34, Washington (U.S. Government Printing Office), p. $393-432$.

Cann, J. R., 1970. Rb, Sr, Y, $\mathrm{Zr}$ and $\mathrm{Nb}$ in some ocean floor basaltic rocks, Earth Planet. Sci. Lett., v. 10, p. 7-11.

Hay, R. L., 1966. Zeolites and zeolitic reactions in sedimentary rocks; Geol. Soc. Am. Special Paper, No. 85.

Norrish, K. and Hutton, J. T., 1969. An accurate X-ray spectrographic method for the analysis of a wide range of geological samples, Geochim. Cosmochim. Acta., v. 33, p. $431-453$.

Robinson, P. T., Flower, M. F. J., Schmincke, H.-U., and Ohnmacht, W., 1977. Low temperature alteration of Oceanic basalts, DSDP Leg 37. In Aumento, F., Melson, W. G., et al., Initial Reports of the Deep Sea Drilling Project, v. 37: Washington (U.S. Government Printing Office), p. 775-794.

Scarfe, C. M. and Smith, D. G. W., 1977. Secondary minerals in some basaltic rocks from DSDP Leg 37; Canadian J. Earth Sci., v. 14, p. 903-910.

Scott, R. B. and Hajash, A., Jr., 1976. Initial submarine alteration of basaltic pillow lavas: A microprobe study, Am. J. Sci., v. 276 , p. $480-501$. 